\author{
تأثير تغيير اقليم بر وضعيت عملكرد برنج در شهرستان رشت \\ محمدحسين ناصرزاده ، بهلول عليجانى و مريم يايدارى'

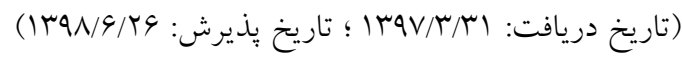

جكيده با توجه به تأثيرهاى تغييرات اقليمى بر محصولات كثاورزى و تهديد امنيت غذايى در سالهاى اخير، اين شرايط يكى از اصلى ترين مسائل اقلـيم

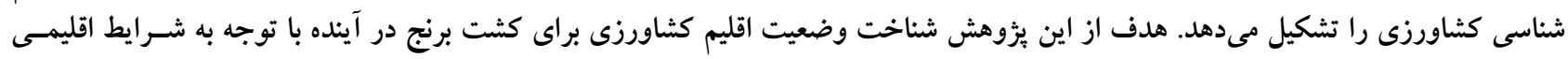

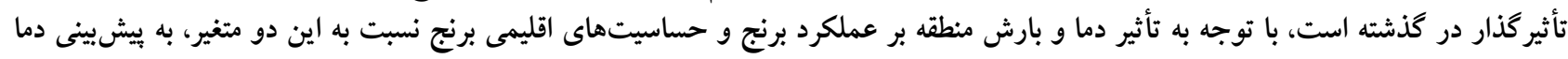

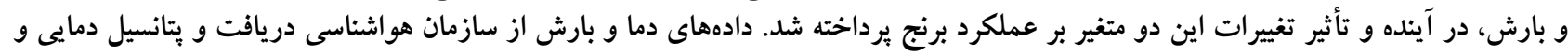

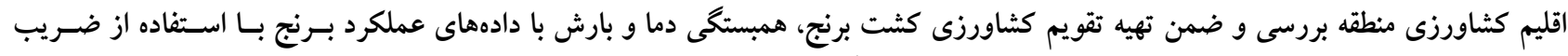

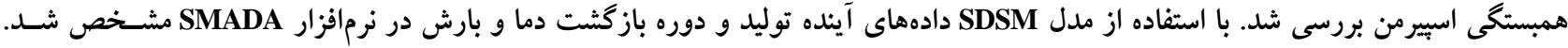

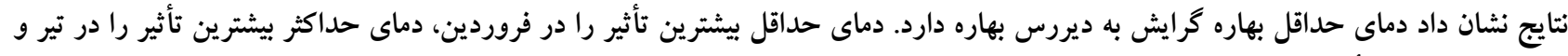

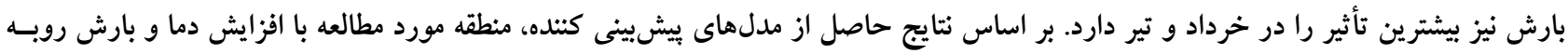

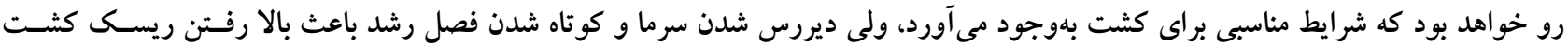
برنج در اين زمان مى رود بود شهود.

وازههاى كليدى: اقليم كثاورزى، يّانسيل دمايى، همبستخى اسبيرمن، مدل SDSM 
راهنماى مناسبى باشد تا با بهره جستن از آن بتـوان راه صسحيح

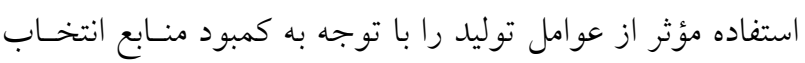

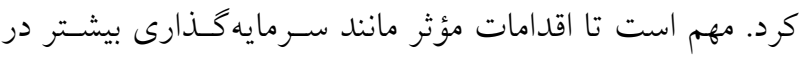
تأسيسات زيربنايى، تحقيقات، توسعه و غيره انجام شود.

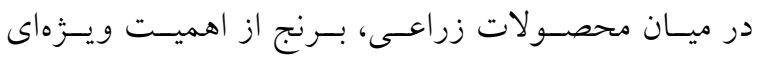

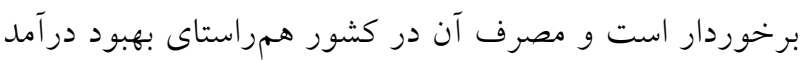
خانوار افزايش يافته و بهعنوان دومين ماده غذايى مهم بعـد از

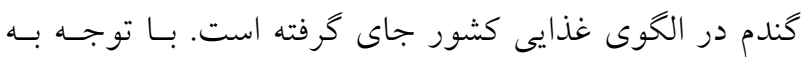
افزايش جمعيت كشور از يكسو و محدوديت توسعه اراضسى

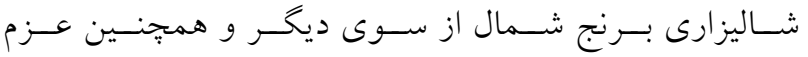

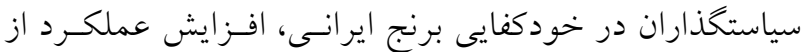

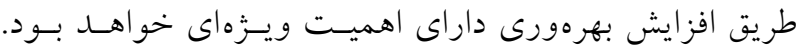

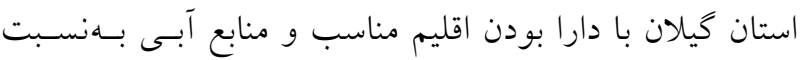

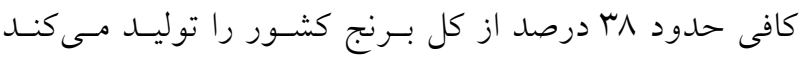
(0). شهرستان رشت با داشتن وسباو هكتـار برنجكارى و

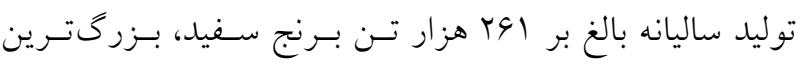

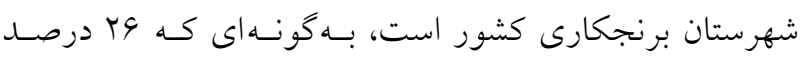

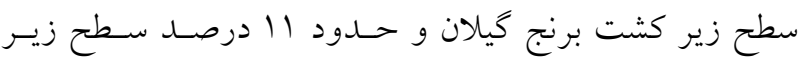
برنجكارى كشور را بهخود اختصـاص داده اسـت. عـلاوه بــــ

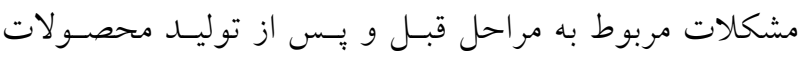

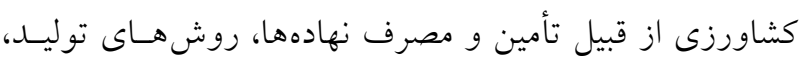

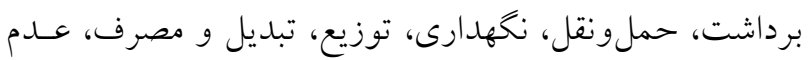

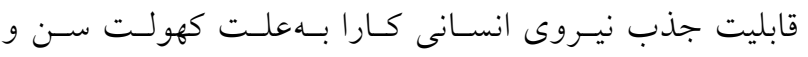
بيسو ادى و عدم تخصـص و مهـارت، سـاخت سـنتى، توليــا

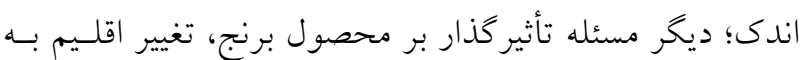

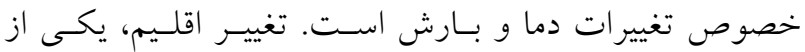
موضوعات داغ است كه در دهلهاى اخير مورد توجسه رسـانه هاى زيادى بوده است. بررسىها نشان مىدهند كه اين بديــــه مىتواند بر بخشهاى مختلف اعـم از منـابع آب، كشـاورزى، محيط زيست، بهلداشت، صنعت و اقتصاد اثرات منفس داشـته باشد (N). براى ييشبينى شرايط آينده، در بيشـر تحقيقـات از

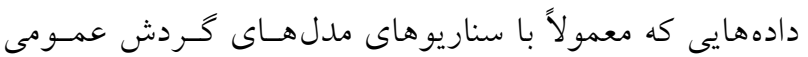

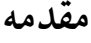

برنج بهعنوان يك ماده غذايى بسيار ارزشمند، مهمترين محصول

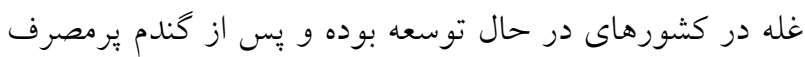

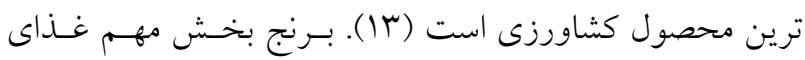

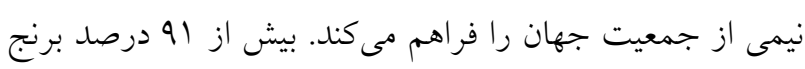

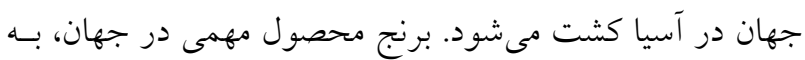

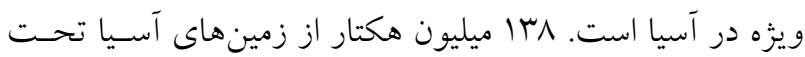

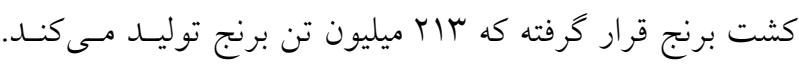

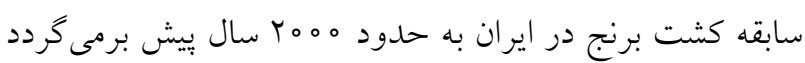

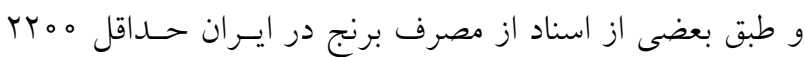

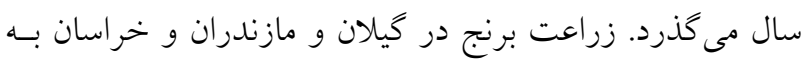

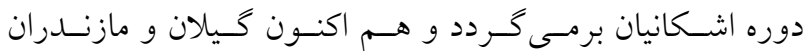

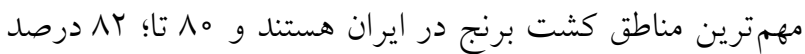
محصول برنج كشور از اين دو استان بهدست مى آيد. در ميان بخشهــاى اقتصـادى كشـورهاى در حـال توسـعه، بخش كشاورزى بهعنوان تأمين كننده غــاى جامعـه از اهميـت قابل ملاحظهاى برخوردار است. به منظور افزايش بهـرهورى در

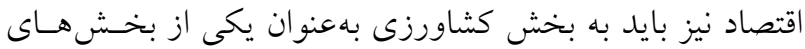

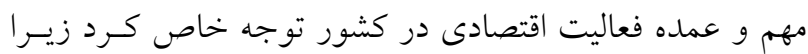

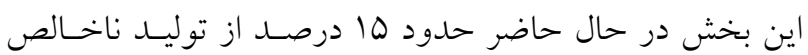

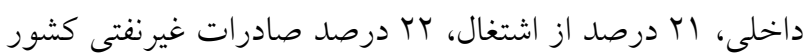

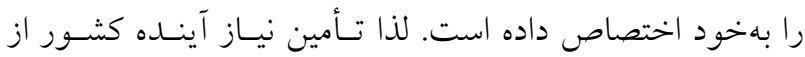
طريق توليد ارقام يرمحصول و با كيفيت مطلوب ضرورى اسـت

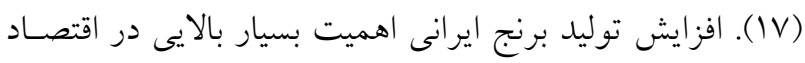

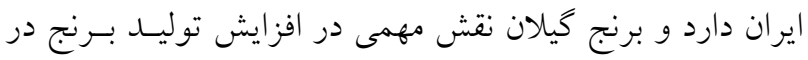
ايران و رسيدن به خودكفايى برنج مى تواند داشته باشد.

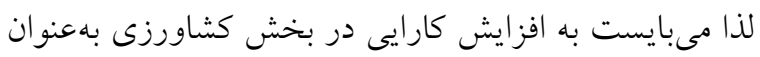
يكى از بخش هاى مهم و عمــده فعاليـت كشـاورزى در كشـور توجه خاص كرد زيرا افزايش رشد بهرهورى در ايسن بخـش بـا توجه به ساختار ويزه اقتصادى كشور مى توانـــ در دسـتيابى بـهـ هدفهاى اقتصادى كمى كننده باشد. در اينصورت توجسه بـهـ

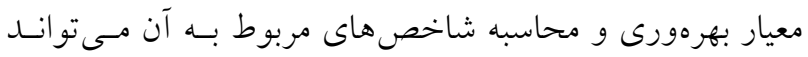


IPCC

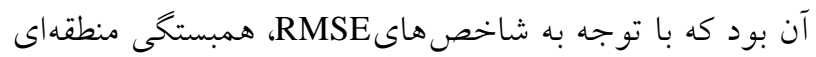

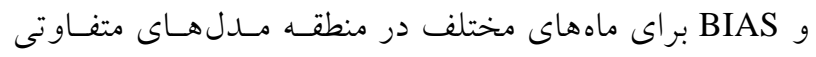

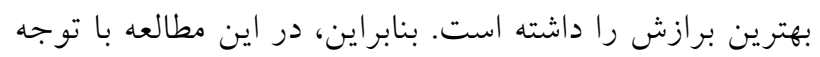

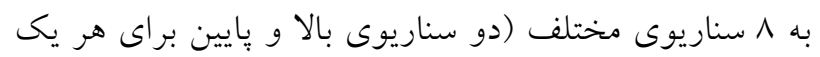
از خانو ادههاى A1، A2، A1 و B2 براى افقهـاى كفتـه شــده

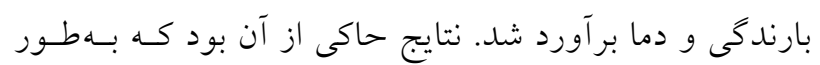

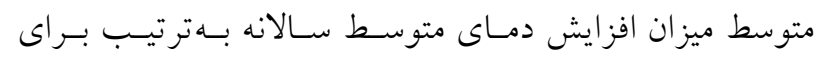

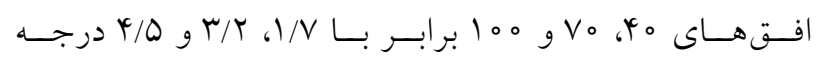

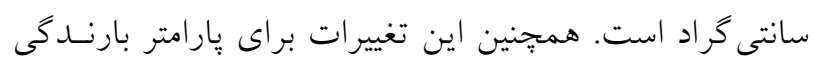

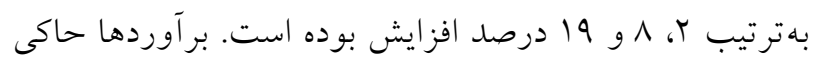

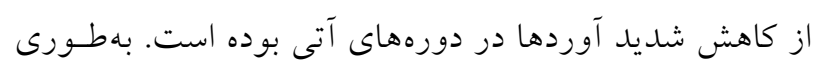

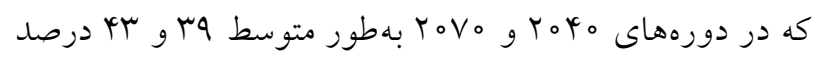

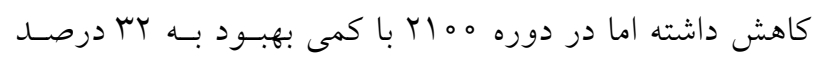

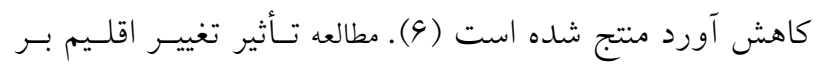

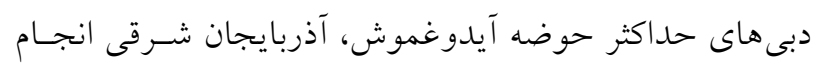

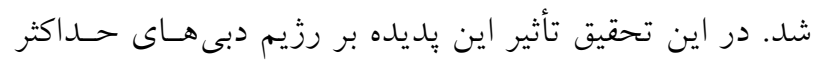

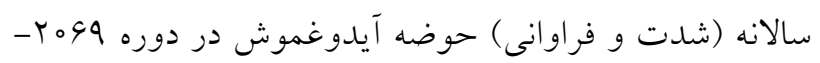

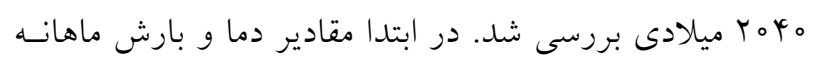

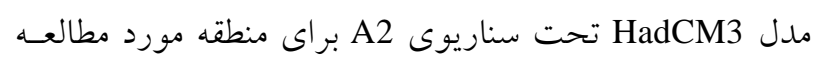

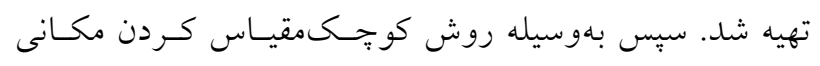

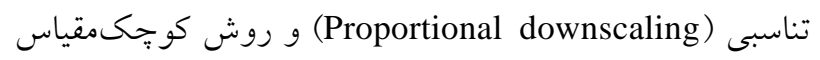

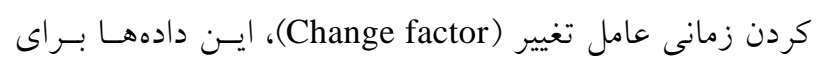

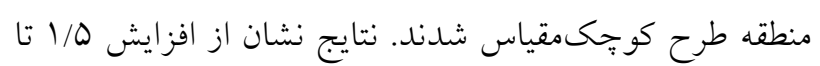

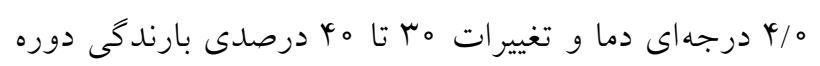

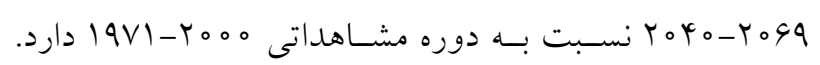
مدل IHACRES براى شـبيه سـازى روانـاب روزانـه حوضـهـ

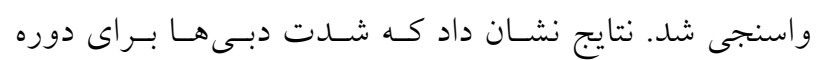

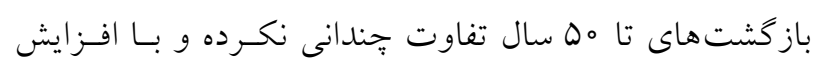

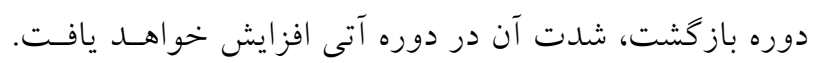

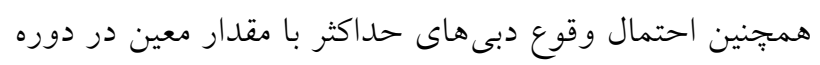

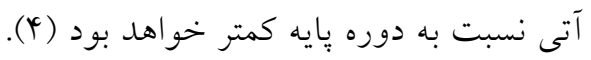

جو (GCM) تعريف شده و توسط هيئت بـين دول تغييـراقليم

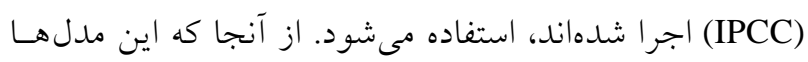

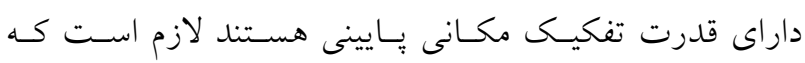

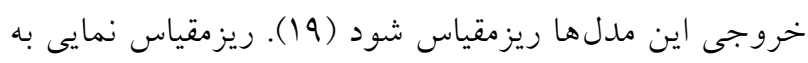

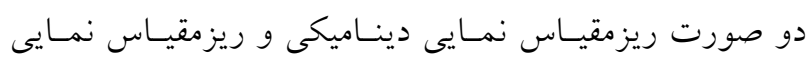

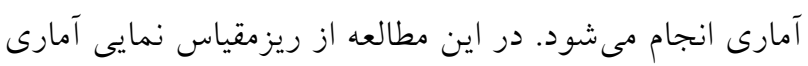

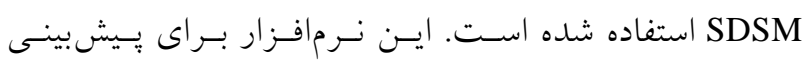

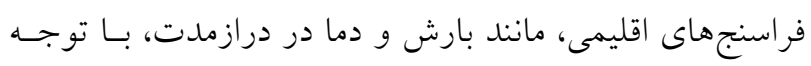
به علامتهاى بزركمقيـاس اقليمسى استفاده مسى شــود. اكثـر

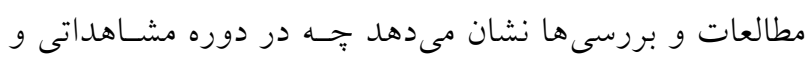

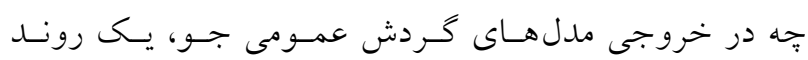

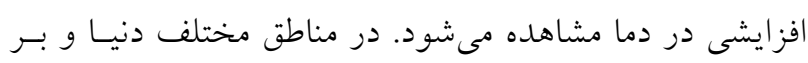

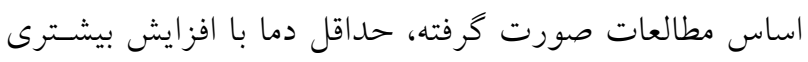
نسبت به دماى حداكثر مو اجه است (Y) (I). در مطالعهاى (IT)

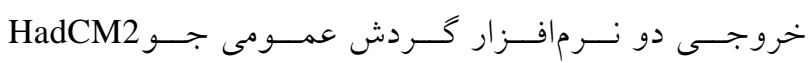

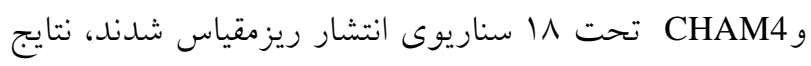
هر دو نرمافزار بيانخر افزايش دماى تمامى استانهاى كشور در

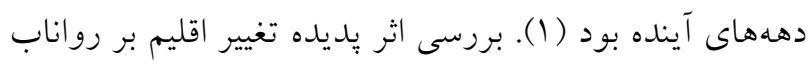

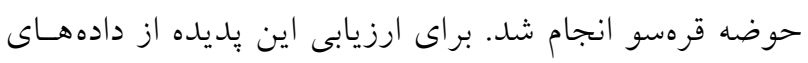
نرمافزار اقليمى HadCM3 تحت سناريو A2 استفاده شد. نتايج

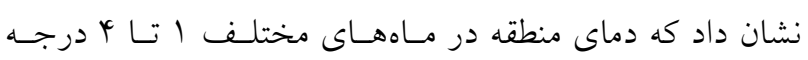

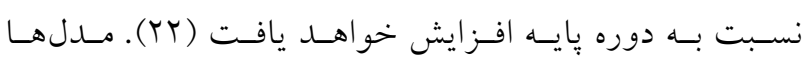

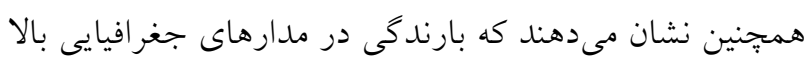

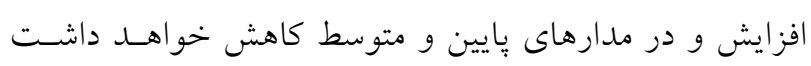

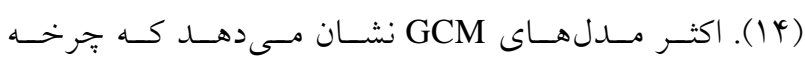
هيدرولوزى متأثر از افزايش دما بودهه و لذا بهدليل تأثير آن بـر آبيارى و درنتيجه توليد مو اد غذايى بايد سياست آبى كشــورها

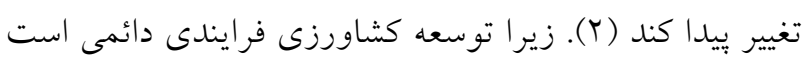

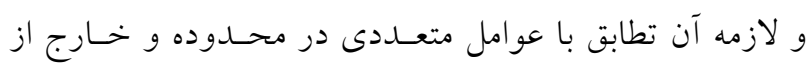
اكوسيستمهاى كشاورزى است (r) (Y). در تحقيقى تحليل اثرات

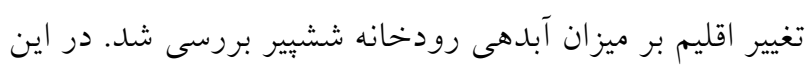

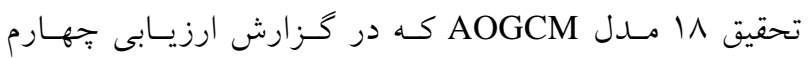


برنج در كذشته است، براى اين كار با درنظر گرفتن معيارهاى

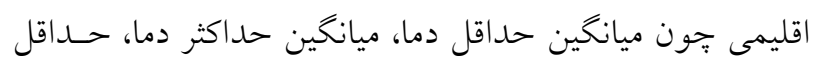

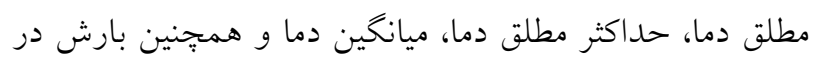

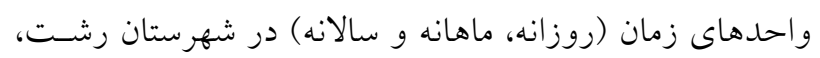

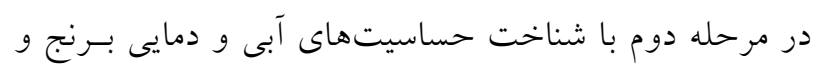

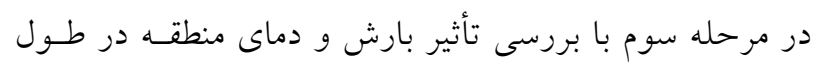

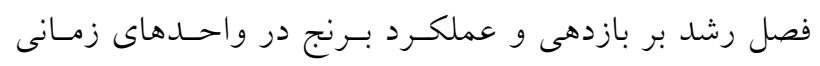

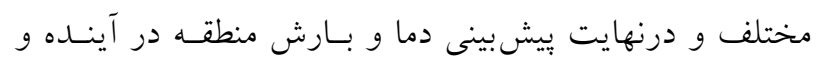

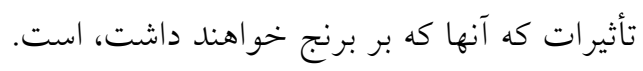

\section{مواد و روشها} منطقه مورد مطالعه كلانشهر رشت واقع در استان كَيلان اسـت.

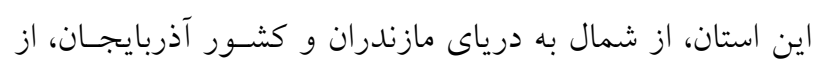

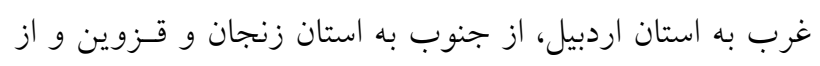

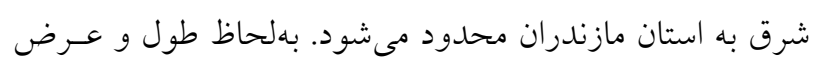

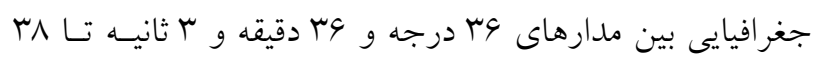

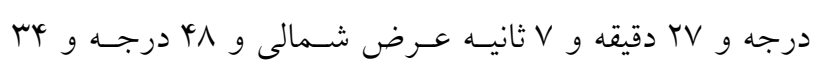

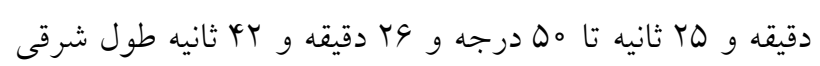
از نصف النهار گرينويج قرار دارد (شكل (1).

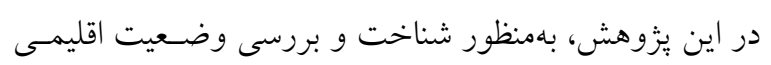

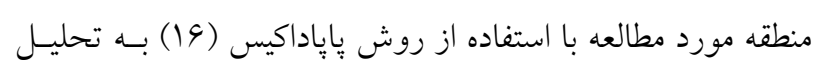

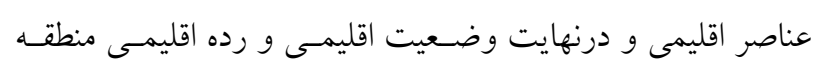

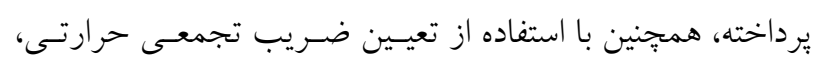

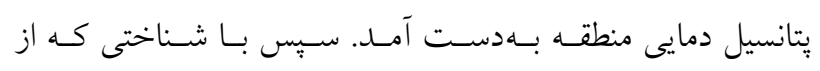

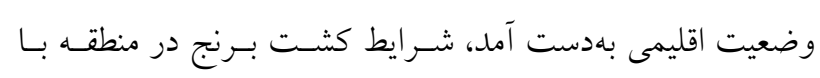

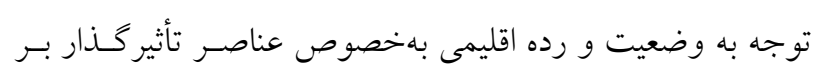

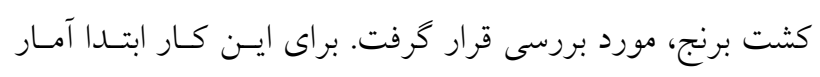

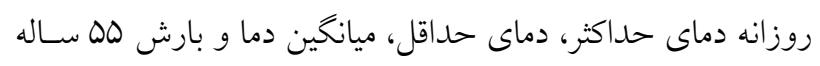

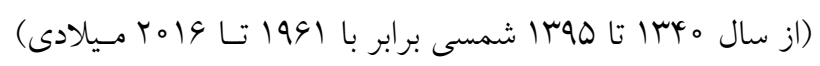

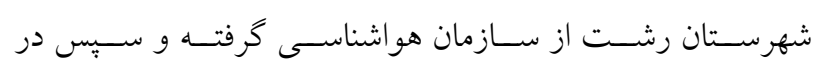
جدولهاى اكسل قرار داده و بررسى كافى بودن سالهاى آمـارى،

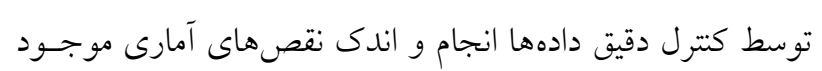

نتايج مطالعهاى نشان داد در سالهايى كه بـارش تابستانه

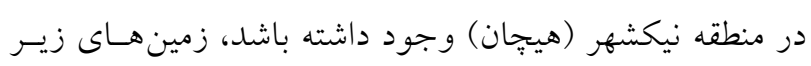

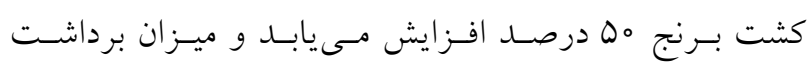

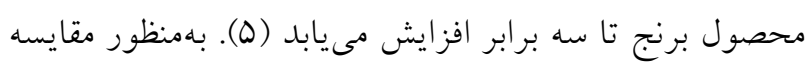

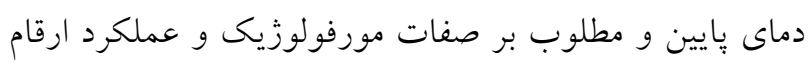

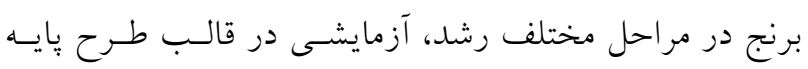

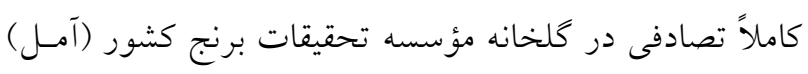

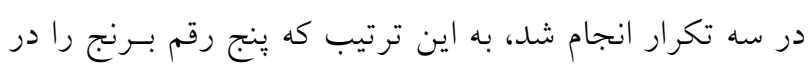

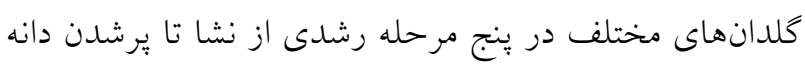

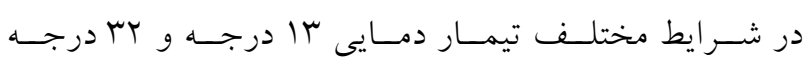

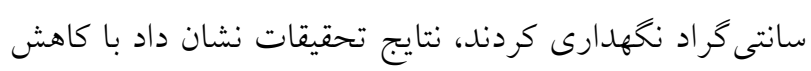

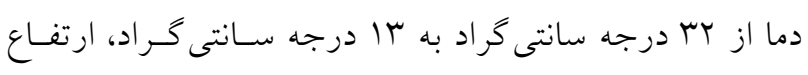

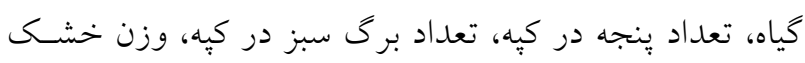

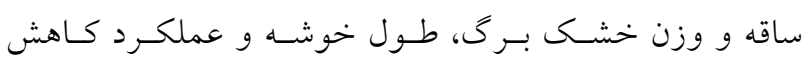

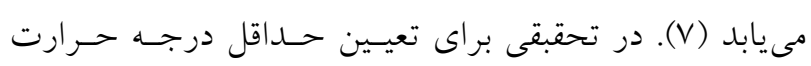

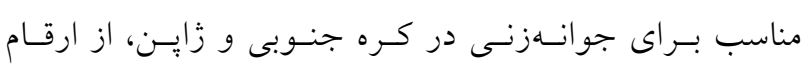

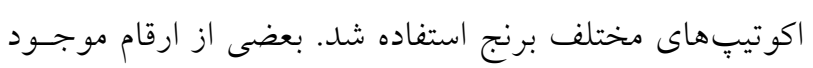

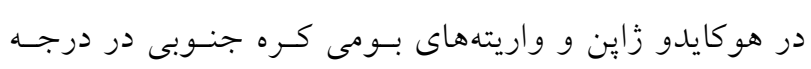

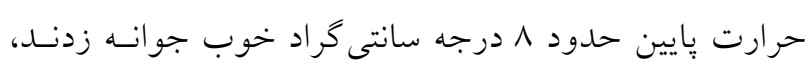
درحالى كه كونههاى برنج در فيلييين و هندوستان حتى در 19

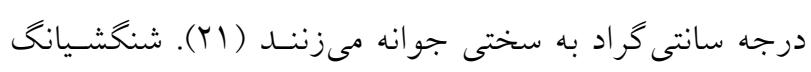

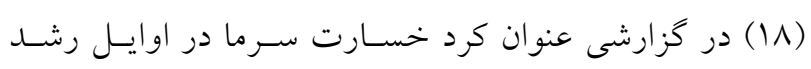

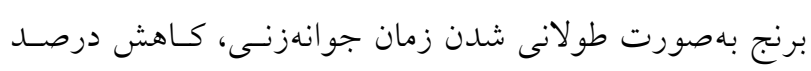

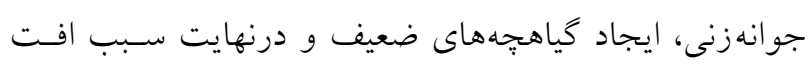

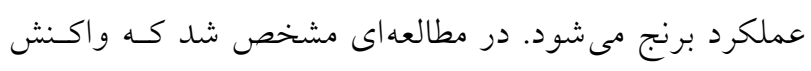

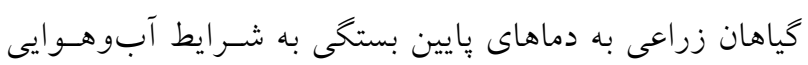

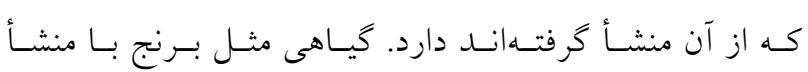
كرمسيرى و نيمه كرمسيرى، نسـبت بـه دماهـاى بـايين بسـيار

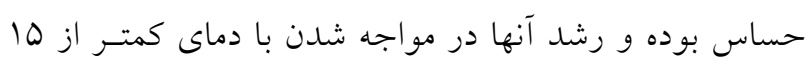

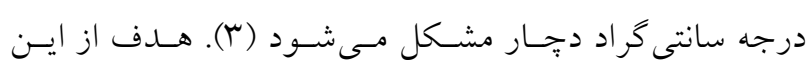

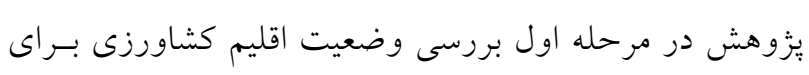

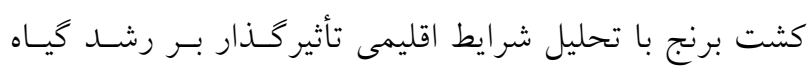




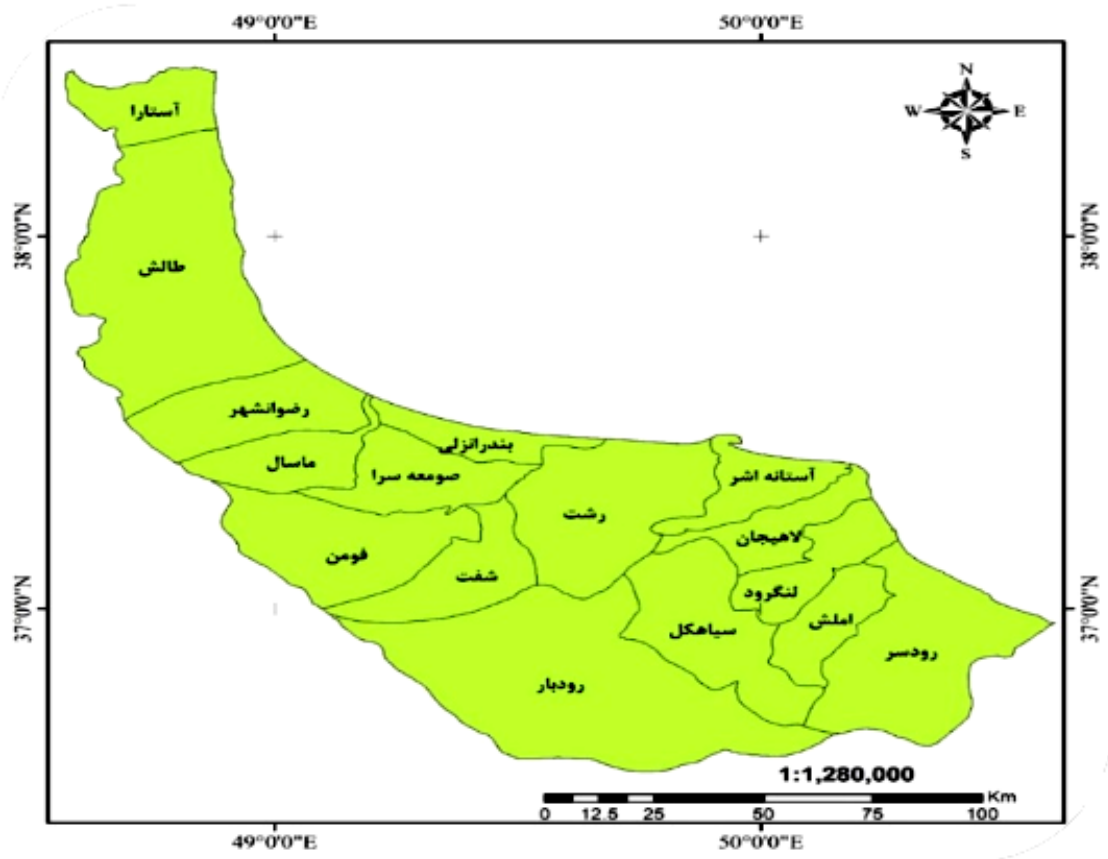

شكل 1. محدوده مورد مطالعه

و بيشتر از آن براى توليد برنج نامطلوب است يـا اينكـه نمسى

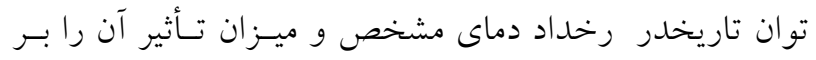

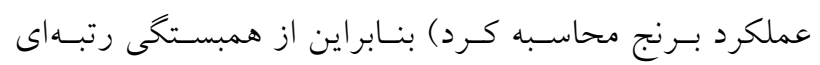

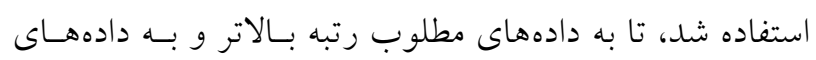

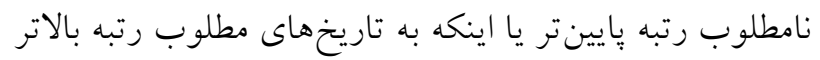

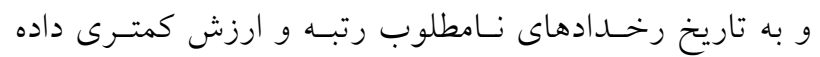

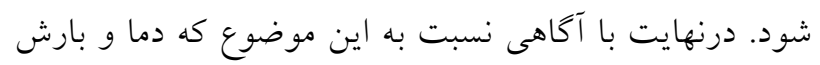

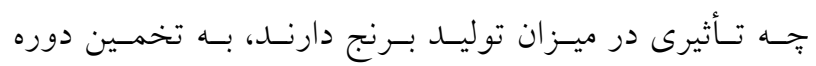

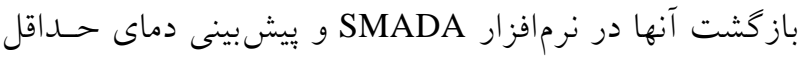

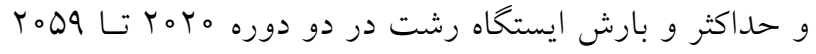

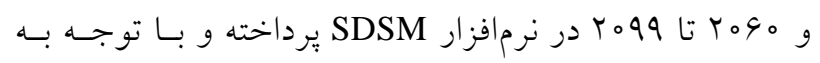

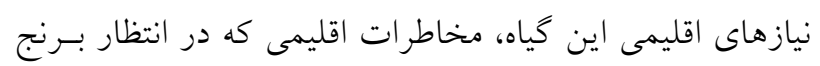

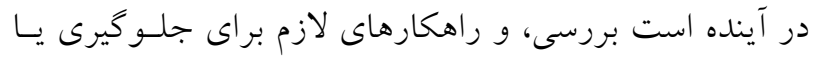

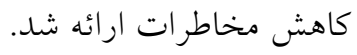

\section{نتايج}

بهمنظور بررسى تنـوع و طبقـه بنــى آبوهـو ايى كشـاورزى

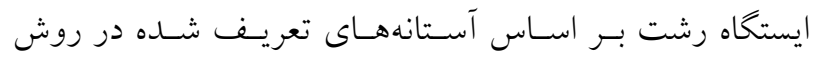

در دوره مطالعاتى با روش تفاضل ها و نسـبتهـا تخمسين زده

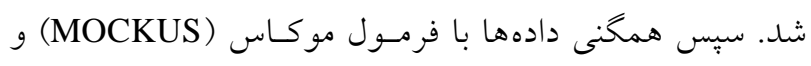

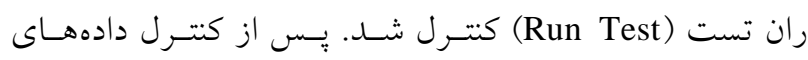

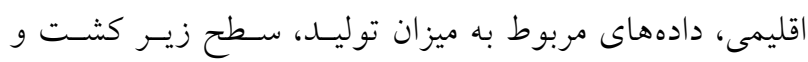

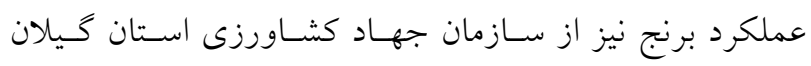

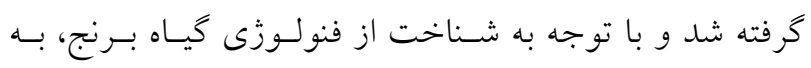
تعيين زمان معمول رخداد حداقل و حداكثر دماى مـورد نيساز

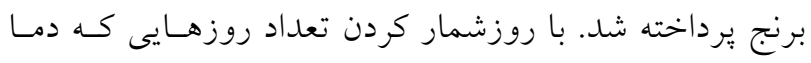

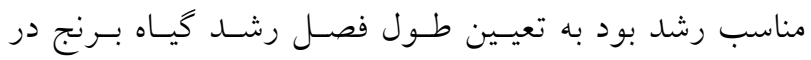
سالهاى مورد مطالعه يرداخته شد و درنتيجه دادههاى روزانـه

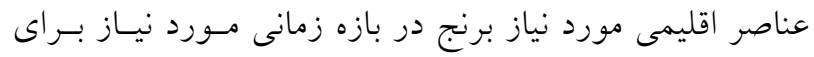

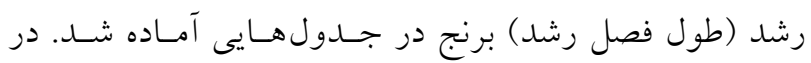

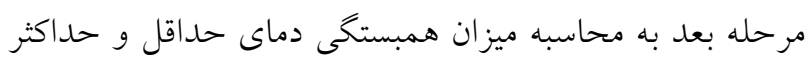

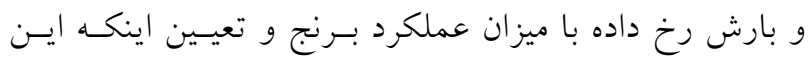

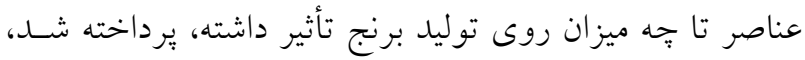

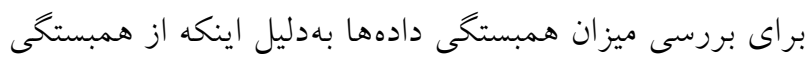

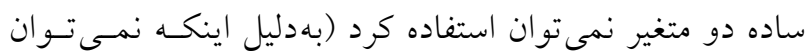
مشخص كرد كه دما تا يكى ميزان خاص مطلوب و بهينه است 
جدول ا. ايستخاه رشت و شاخصهاى مربوطه در روش يإياداكيس

\begin{tabular}{|c|c|c|c|c|c|c|c|c|c|c|c|c|c|}
\hline$\frac{G}{i}$ & $\begin{array}{l}q: \\
\dot{q} \\
\dot{z}\end{array}$ & $\begin{array}{l}q \\
q \\
q \\
q \\
\varepsilon \\
\varepsilon\end{array}$ & $\begin{array}{l}\dot{\varepsilon} \\
\dot{\xi} \\
\xi \\
\xi \\
\xi\end{array}$ & 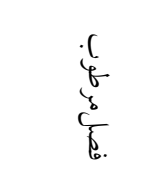 & $\begin{array}{l}q \\
\underline{q} \\
\varepsilon \\
\varepsilon\end{array}$ & $\begin{array}{c}\text { c. } \\
\text { है. } \\
\text { c. }\end{array}$ & 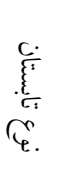 & 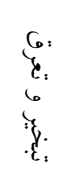 & $\begin{array}{l}\dot{z} \\
\xi \\
\tilde{z} \\
\delta \\
\delta\end{array}$ & $\begin{array}{l}\xi \\
\xi \\
\xi \\
\xi\end{array}$ & $\underline{\varepsilon}_{\varepsilon_{i}}$ & 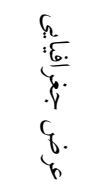 & عناصر \\
\hline $9,1,4,1$ & $\mathrm{ME}$ & $1 / \Delta r$ & Apr-Jun & Mar-Sep & Su2 & ci & g & 909 & $I V / \mu$ & 1400 & $-1 / 9$ & $r V / 19$ & ايستگاه رشت \\
\hline
\end{tabular}

\section{جدول r. ميانگين درجه حرارتهاى تجمعى فعال در رشت}

\begin{tabular}{|c|c|c|c|c|c|c|c|c|c|c|c|c|c|}
\hline 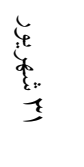 & $\begin{array}{l}\frac{u}{\breve{y}} \\
\underline{z}\end{array}$ & $\begin{array}{l}i_{1} \\
1\end{array}$ & 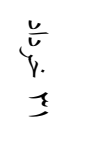 & $\underbrace{\vdots}_{\frac{1}{J}}$ & 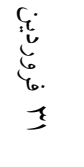 & $\frac{\xi}{\underline{g}}$ & $\varliminf_{0}^{\underline{1}}$ & $\begin{array}{l}5 \\
0 \\
0\end{array}$ & $\frac{\grave{y}}{\mathfrak{T}}$ & $\frac{C}{\frac{C}{1}} \frac{1}{0^{\prime}}$ & $\begin{array}{l}\text { th } \\
7 \\
0\end{array}$ & $\delta$ & زمان \\
\hline GVGr & DQFV & D.ro & FIGY & $M T V$ & rVTq & TYAT & $191 \mathrm{~T}$ & IVAS & IFYG & 1091 & GYD & 。 & \\
\hline GOKY & DVYG & FNIF & mapl & M101 & TOIA & 1994 & IVr。 & 1011 & IrG4 & 1091 & GYO & r & ايستخاه رشت \\
\hline$\Delta D I T$ & 1499 & rVNA & 1911 & $r|r|$ & $101 \pi$ & G از IIV & - & - & - & r & 940 & 10 & \\
\hline
\end{tabular}

داشته باشد. بهمنظور مطالعـهـ ايسن محسدوده حرارتـى در منطقـه

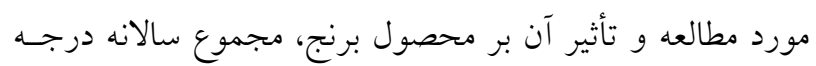

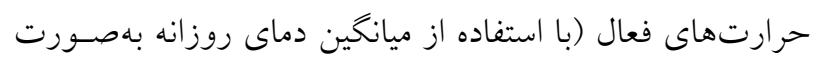

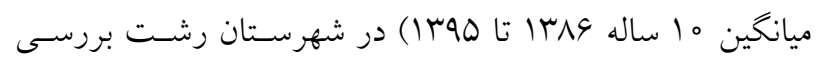
شد. براى اين كار (جدول Y) درجه حرارتهاى فعال بهصورت

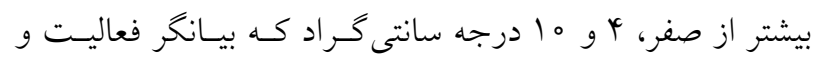
سكون بسيارى از فعاليتهاى گياهى است، محاسبه شد.

\section{دماى مورد نياز برنج در مراحل مختلف رشد}

مجموع درجه حرارت لازم (بالاى ه ا درجه سانتى گـراد) بـراى كياه برنج طى دوره رشد ه 4\% درجه سانتى گراد بوده و دماهاى مورد نياز طى مراحل رشدونمو در مرحله توليـد جوانسه حسدود

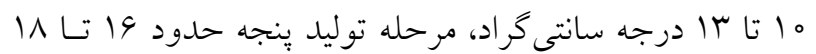

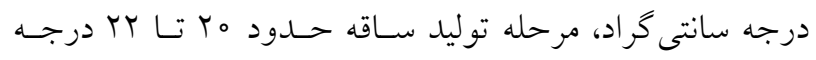
سانتى گراد، مرحله توليد گل حدود r r تا ها درجه سانتى گـراد، مرحله رسيدن حدود ها تا مب درجه سانتى گراد و بهطور كلى

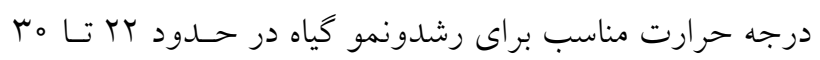

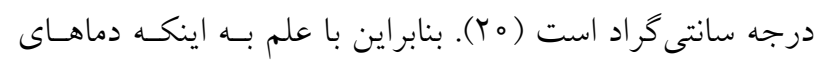

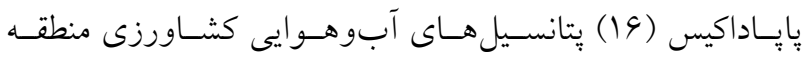

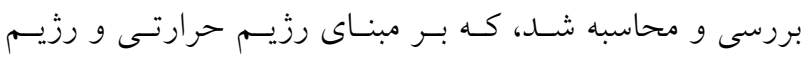
رطوبتى ايستخاه رشت در رده اقليمى مديترانهاى قرار مى گيسرد. در اين رده اقليمى محصولات باغى جون زيتـون، انجيـر، بـادام زمينى، مركبات و انـواع سـبزيجات ديـر كاشـت و زودكاشـت عملكرد خوبى دارند. بنابراين با توجه بـهـ بررسـى انجـام شـده،

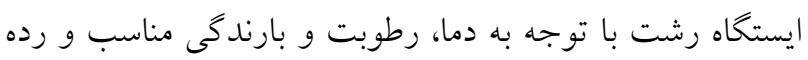
اقليمى كه در آن قرار دارد در مجموع از شـرايط مناسـبى بــراى كشت برنج برخوردار است(جدول ()).

بررسى يتانسيل گرمايى (درجه حرارتهاى فعال) در منطقـه مورد مطالعه درجه حرارتهاى فعال كه در واقع محدوده حرارتى فعاليـت و رشدونمو گياهان است و شامل مجموع درجه حرارتهاى فعال بيشتر از صـفر، لأو ه ا درجـه سـانتى گـراد اسـت، بسـيارى از

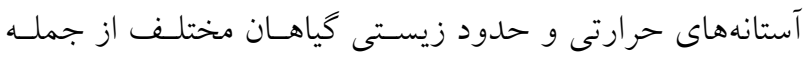
برنج (بيشتر از ه ا درجه سانتى گـراد) را شـامل مسى شـود، ايسن محدوده حرارتى مىتواند تأثيراتى تعيين كننده بر رشــ كياهـان 
جدول \&. تاريخهاى بهينه تقويم كشاورزى گياه برنج در رشت

\begin{tabular}{|c|c|}
\hline تاريخ بهينه & 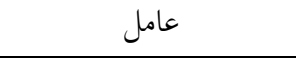 \\
\hline r بروردين & زمان آغاز توليد جوانه \\
\hline مبروردين & زمان آغاز توليد ينجه \\
\hline ش Y ارديبهشت & زمان آغاز توليد ساقه \\
\hline وخرداد & زمان آغاز توليد گل \\
\hline q خرداد & زمان آغاز مرحله رسيدن \\
\hline
\end{tabular}

بهطور مشخص از اصلىترين عوامل اقليمى مؤثر در كشت برنج

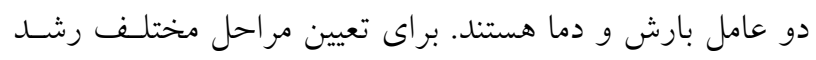

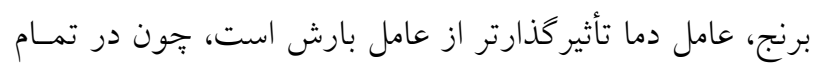

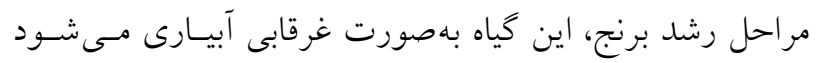

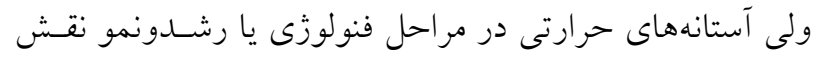

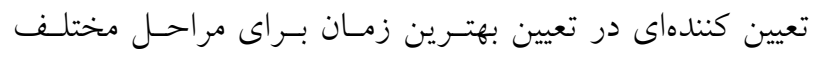

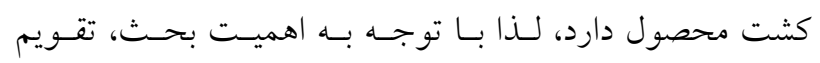

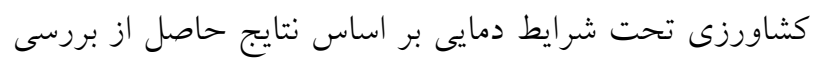

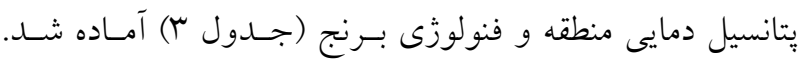

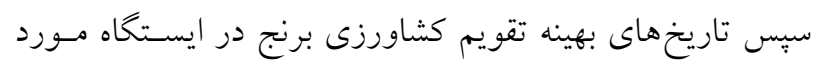
مطالعه مشخص شد(جدول f).

تعيين زمان آخرين و اولين آخـرين تساريخ رخــداد حسداقل دماى مورد نياز برنج و تعيين طول فصل رشد ومد وندين

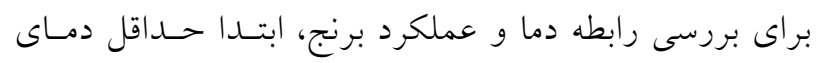

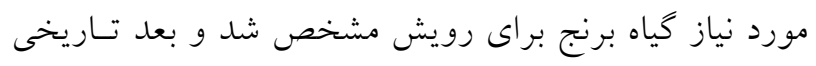

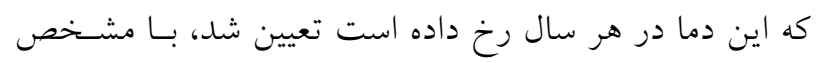

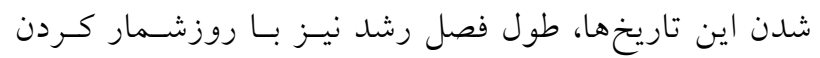

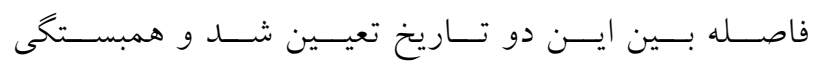

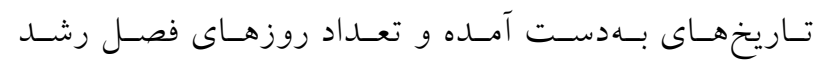

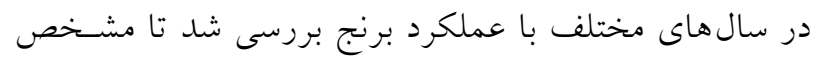

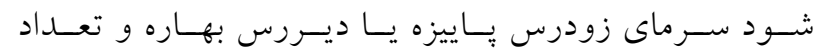

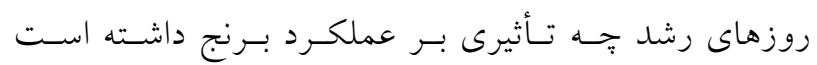

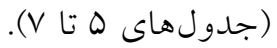

جدول r. شاخصهاى دمايى تقويم كثاورزى گياه برنج در رشت

\begin{tabular}{|c|c|}
\hline درجه حرارت & عامل \\
\hline ها تا سا درجه سانتى كراد & دماى آغاز توليد جوانه \\
\hline وا تا ها درجه سانتى كراد & دماى آغاز توليد بِنجه \\
\hline 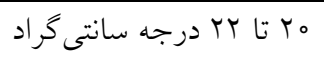 & دماى آغاز توليد ساقه \\
\hline r T تا T درجه سانتى گراد & دماى آغاز توليد كل \\
\hline هT تا •r درجه سانتى گراد & دماى آغاز مرحله رسيدن \\
\hline
\end{tabular}

مورد نياز بـر اى مراحـل مختلـف رشـــ بـرنج جـهـ دماهـايى

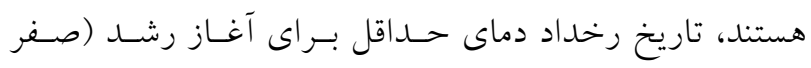

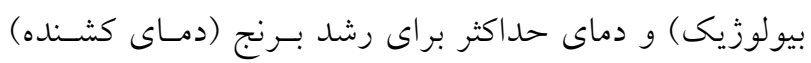

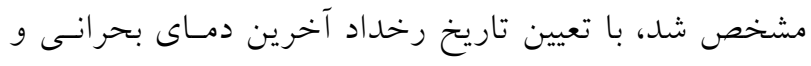

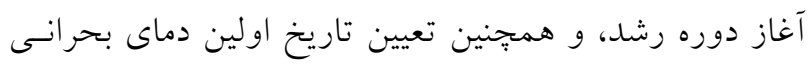

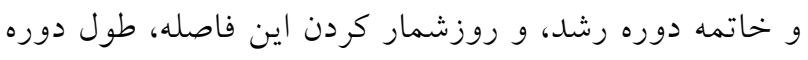

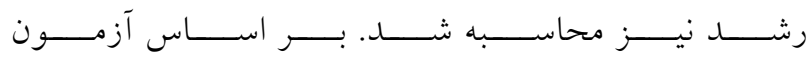

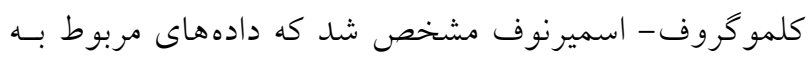

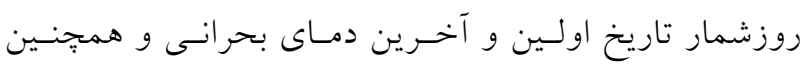

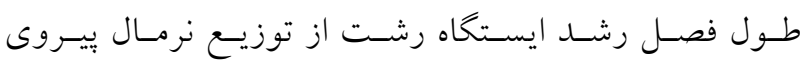

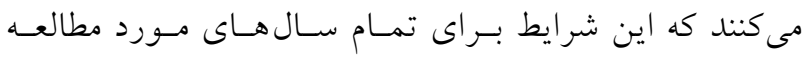

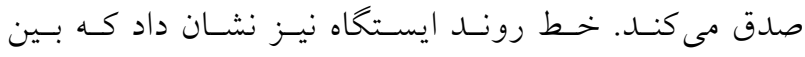

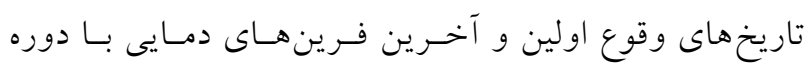
زمسانى داراى همبسـتخى ضـعيف و منفسى بـوده و و همجنـين بررسى روند در دورههاى زمانى مورد مطالعه مشـخص كـرد تأثيرى در نوسان آنها ندارد.

\section{تقويم كشاورزى كشت برنج در ايستخاه رشت}

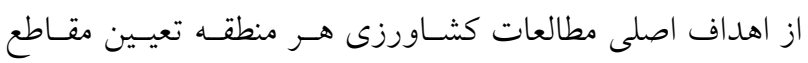
بهينه زمانى مر احل كاشت، داشت و برداشت كونههاى مختلـف

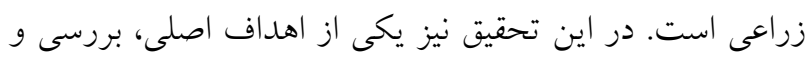

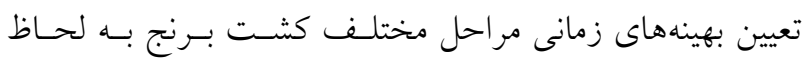

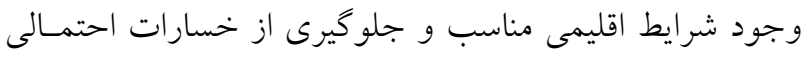
ناشى از نوسانات اقليمى اين كياه در منطقه مورد مطالعه اسـت. 
جدول ه. تاريخ وقوع حداقل دماى مورد نياز رشد و رتبهاى تعلق گرفته به اين تاريخها و تعداد روزهاى فصل رشد

\begin{tabular}{|c|c|c|c|c|c|}
\hline \multicolumn{2}{|c|}{ رتبههاى تعلق گرفته به تاريخ وقوع دماى حداقل } & \multicolumn{3}{|c|}{ تاريخ وقوع حداقل دماى مورد نياز براى آغاز رشد برنج (ما درجه سانتى گرا } & \multirow{2}{*}{ سال } \\
\hline آخرين تاريخ & اولين تاريخ & طول فصل رشد & آخرين تاريخ & اولين تاريخ & \\
\hline$\wedge$ & $r$ & TOS & $9 / 11$ & $1 / 1$ & irvq \\
\hline$r$ & 9 & ro。 & $\Lambda / Y \Lambda$ & $\mid r / T r$ & $\| \mu \Lambda_{0}$ \\
\hline 9 & 9 & TQY & $9 / V$ & $I T / T A$ & $|\Pi N|$ \\
\hline r & r & $T r V$ & N/Tr & $1 / 1 T$ & ITNK \\
\hline 0 & 0 & YYA & $9 / 4$ & $1 / \pi$ & IrNr \\
\hline 10 & r & rq० & $10 / T$ & $1 / 11$ & IrNA \\
\hline$r$ & 10 & r99 & $\Lambda / T \Lambda$ & ITN & IrNo \\
\hline 0 & $r$ & rms & $9 / r$ & $1 / 1 T$ & $\mid \Pi \wedge \varphi$ \\
\hline$r$ & 9 & rq1 & $N / T V$ & $|r /| \mid$ & IrAV \\
\hline 9 & 1 & rTs & $9 / V$ & $1 / T V$ & $\| \mu \Lambda$ \\
\hline 10 & $r$ & TVI & $10 / 4$ & $1 / 9$ & $1 \% \wedge q$ \\
\hline r & 0 & TrV & $N / 19$ & $1 / 0$ & $1 \pi 90$ \\
\hline 0 & $r$ & rM & $9 / \pi$ & $1 / 11$ & $|r q|$ \\
\hline v & $\wedge$ & rqA & $9 / 1 \pi$ & $\mid r / r_{0}$ & Irat \\
\hline 1 & $r$ & TIV & $N / I^{4}$ & $1 / 14$ & rat \\
\hline v & 4 & TAY & $9 / 14$ & $I Y / T V$ & Irat \\
\hline r & 0 & TKY & $\Lambda / \mu_{0}$ & $1 / \mu$ & 1790 \\
\hline
\end{tabular}

توليد داده دما و بارش آينده توسط مــل آنس SDSM و مقايسـه

\section{آن با دوره مشاهداتى}

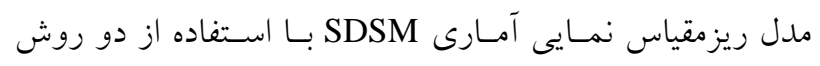

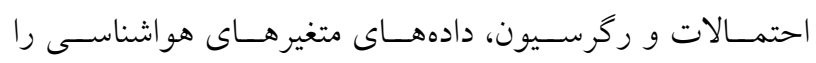

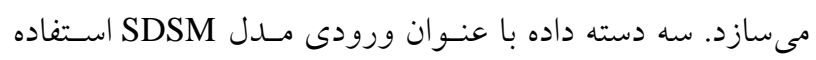
مى شود. اولين دسته، دادهاى مشاهداتى هستند كـه از سـازمان

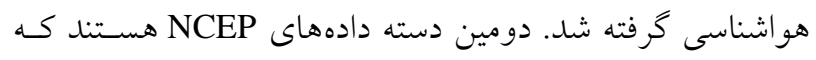

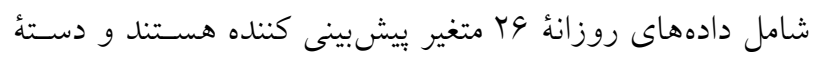

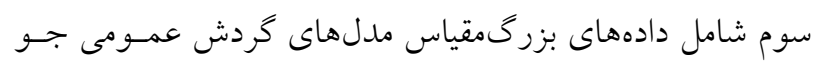

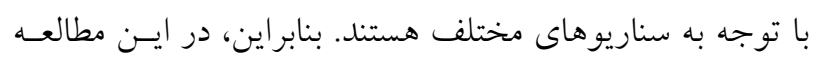

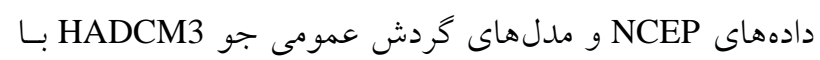

احتمال دوره بازگشت حالت هاى مطلـوب دمـايى و بــارش منطقه محاسبه تاريخ وقوع آخرين دماى حدى (حسداقل بهـاره) بـه

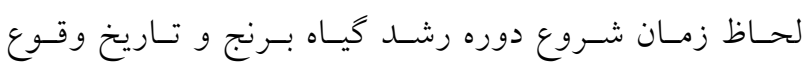

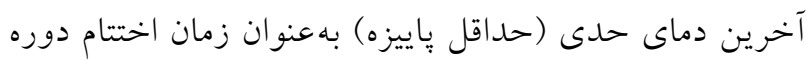

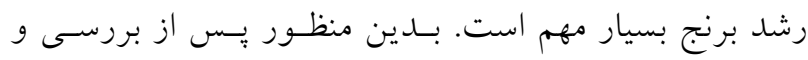

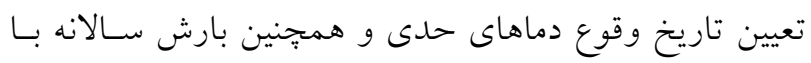

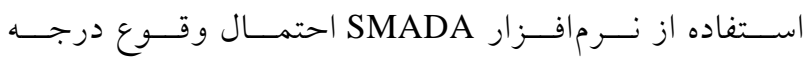
حرارتهاى حدى و ميزان مجموع بارش سالانه در دورههاى

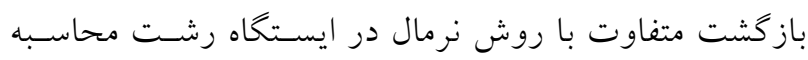

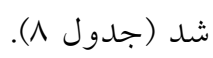


جدول و. ميزان همبستخى تاريخهاى وقوع دماى حداقل و طول فصل رشد با عملكرد برنج در شهرستان رشت

\begin{tabular}{|c|c|c|c|c|c|c|c|c|c|}
\hline$\xi$ & $\tilde{\xi}$ & $\begin{array}{l}\xi . \\
\xi \\
\xi\end{array}$ & $\xi$ & $\tilde{\xi}$ & 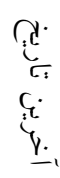 & $\xi$ & 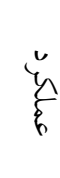 & 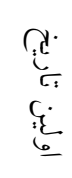 & زال \\
\hline \multirow[t]{17}{*}{$0 / 1 Y q$} & 4111 & TOS & $0 / 1 Y Y$ & $r$ & $\wedge$ & $0 / \mathrm{V} / \mathrm{Y}$ & $\mu$ & 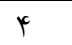 & $1 \% \mathrm{Vq}$ \\
\hline & $q V \circ V$ & ro。 & & 0 & q & & 0 & 9 & 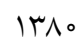 \\
\hline & YQVY & TOY & & 0 & 4 & & 0 & 4 & $|r N|$ \\
\hline & FVYT & TrV & & $r$ & r & & 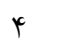 & $\mu$ & IrNT \\
\hline & DIST & TYA & & 0 & 0 & & 0 & 0 & سNו \\
\hline & firdo & TG० & & $\mu$ & 10 & & r & $r$ & IrNA \\
\hline & qro。 & r49 & & 4 & t & & 9 & 10 & $\| \mu \Delta$ \\
\hline & $\langle\wedge|\psi|$ & & & r & 0 & & r & $\mu$ & IrAs \\
\hline & GeYs & YGI & & 0 & $\varphi$ & & r & 9 & $I \mu \wedge V$ \\
\hline & yras & TYG & & $\mu$ & 9 & & r & 1 & $\| \mu \wedge$ \\
\hline & FYYY & rVI & & r & 10 & & $y$ & r & $1 \% \wedge q$ \\
\hline & YQSYl & TrV & & 0 & r & & 0 & 0 & $1 \mu q 0$ \\
\hline & Gruk & גוץ & & $r$ & 0 & & r & $r$ & $|r q|$ \\
\hline & $\varphi \Delta \wedge q$ & r\&A & & 0 & V & & 0 & $\wedge$ & Irar \\
\hline & YAIV & TIV & & r & 1 & & r & r & سra \\
\hline & $Y \Delta \Delta \Delta$ & TEY & & 0 & V & & 0 & 9 & Irat \\
\hline & $Y \Delta \Delta^{\circ}$ & ry & & 0 & t & & 0 & 0 & 11490 \\
\hline
\end{tabular}

جدول V. ميزان همبستخى حداكثر، حداقل و ميانگين دماى ماهانه و همجنين بارش ماهانه با عملكرد سالانه برنج در شهرستان رشت

\begin{tabular}{|c|c|c|c|c|c|}
\hline مرداد & تير & خرداد & ارديبهشت & فروردين & عناصر اقليمى \\
\hline .1190 & $\circ / \mu V y$ & $0 / T V I$ & $0 / T 91$ & $0 / 01 Y$ & حداكثر دما \\
\hline $0 / r M V$ & - MYQ & O/TKY & $0 / 01 \mathrm{~V}$ & $0 / \mu Y \wedge$ & حداقل دما \\
\hline - TOV & $\circ / 4 V V$ & $\circ /$ MNV & - MUS & OTYA & ميانگين دما \\
\hline.$/ 009$ & $0 / 14 \lambda$ & O/Tr &.$/ 191$ & $0 / Y 19$ & بارش ماهانه \\
\hline
\end{tabular}

جدول ^ ـ دوره بازگشت تاريخ وقوع اولين و آخرين دماى بحر انى و مجموع بارش سالانه در ايستخاه رشت

\begin{tabular}{|c|c|c|c|c|c|}
\hline مهاله & TlQ & • 1 ساله & ل & r Tاله & دوره باز كشت \\
\hline rارديبهشت & צץ فروردين & 19 فروردين & ع أ فروردين & كا فروردين & تاريخ اولين دماى بحرانى \\
\hline v V V V & آذر & 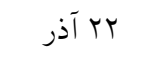 & ع 19 آذر & ه آذر & تاريخ آخرين دماى بحرانى \\
\hline TOYQ & TYIV & rodr & 1N49 & 140. & مجموع بارش سالانه \\
\hline
\end{tabular}


جدول 9. مقدار همبستخى جزئى بين دادهاى بزرگمقياس (NCEP) و دادههاى مشاهداتى

\begin{tabular}{|c|c|c|c|}
\hline RMSE & $\mathrm{R}^{2}$ & Index & شاخص \\
\hline ०/AV & $\circ / 9 \mu$ & Min Temperature & درجه حرارت حداقل \\
\hline.$/ 99$ & $\circ / 9 \mu$ & Max Temperature & درجه حرارت حداكثر \\
\hline$\circ / Q Y$ & $0 / 9 Y$ & Precipitation & 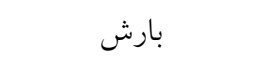 \\
\hline
\end{tabular}

خواهيم بود، در مقياس بـارش فصـلى بيشـترين مقــدار ايسن افزايش در فصل بهار اتفاق مى افتد بهنحوى كه بـارش فصـل بهـار در دوره

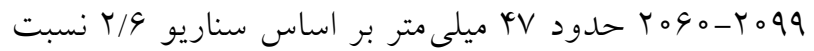
به دوره مشاهداتى افزايش خواهد داشت. همجِنين در مقياس

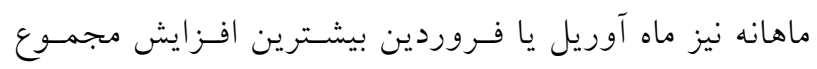

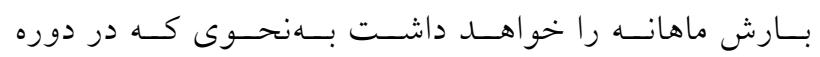

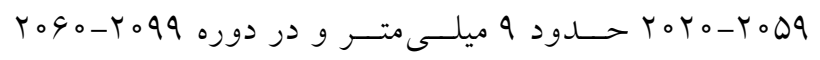
حدود اب ميلى متر نسبت به دوره مشاهداتى افزايش خواهـد

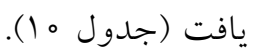
بر اساس دادههاى توليد شده توسط مدل بر اسـاس سـناريو

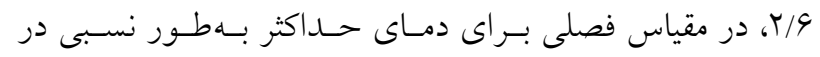
فصل هاى تابستان و زمستان شاهد كاهش دما و در بهار و يـاييز شاهد افزايش دما خواهيم بود، براى مثال ميانخين حداكثر دماى مربوط به فصل زمستان در دوره

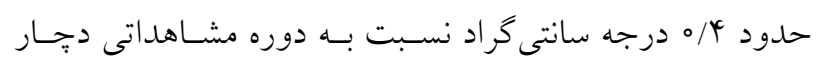
كاهش خواهد شد. همجزنين در فصل بهار ميانخين حسداكثر دمـا در دوره سانتى كراد درجه نسبت به دوره مشاهداتى دجّار افزايش خواهد شد. در مورد دماى حداقل نيز اين رونـد تكــار شـده اسـت و فصل هاى زمستان و تابستان در دورههاى آتسى نسـبت بـه دوره مشاهداتى با كاهش دما و فصل هاى بهار و باييز با افـزايش دمـا همراه هستند و درنتيجه ميانخين دما نيز بر همين اساس خواهــ بود يعنى در فصل زمستان و تابستان كاهش و در فصـل بهـار و ياييز افزايش دما نسبت بـه دوره مشـاهداتى مشـاهده مسى شـود

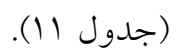

سـناريوهاى RCP2.6 و RCP 4.5 و RCP از سـناريوهاى اقليمى CMIP5 از لينـى ( http:/ccds-dscc.ec.gc.ca ) بـر اساس طول و عرض جغر افياى رشت دريافت شد، سـيس در

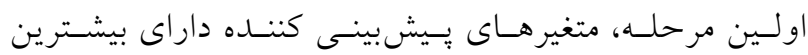
همبستخى با دادههاى مشاهداتى شناسايى و انتخـاب شـــند،

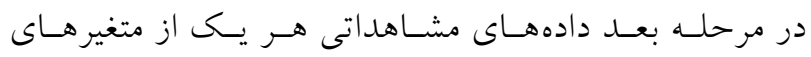
بيشبينى شونده به دو قسمت براى واسنجى و صحتسـنجى مدل به كار برده شد. در مرحله واسنجى و اعتبارسـنجى مــدل

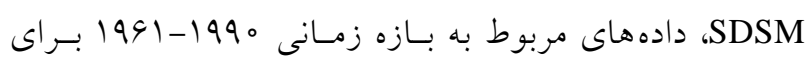

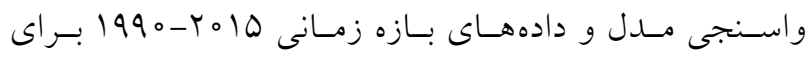
اعتبارسنجى مدل استفاده شد. نتايج صحتسنجى مدل نشـان داد دادههــاى دوره يّايسهه بــا دادههــاى توليـــ شــه در دوره

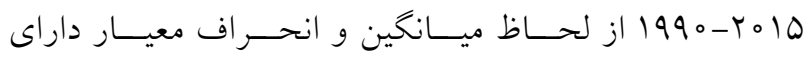
شباهت نسبى بـوده و اخـتلاف بسـيار نـاجيز بـا هــم دارنــد،

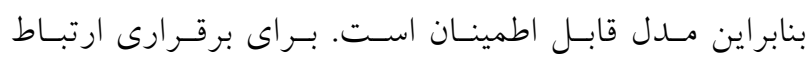

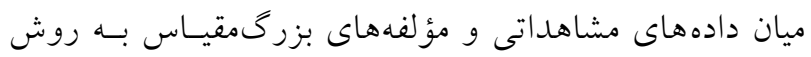

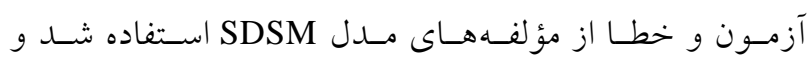

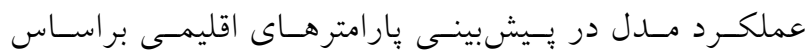
شـاخص ضـريب تشـخيص (R²) و جـذر ميـانخين مربعـات (RMSE) در مرحله بعد بر اساس سـناريوهاى RCP2.6 4.5 و 4.6 RCP 8.5 از سـناريوهاى اقليمسى CMIP5 دادههــاى آينـده در بازهاى با دادههاى مشاهداتى مقايسه شد. بر اساس دادههاى توليد شده توسط مدل براى بـارش، در كل شاهد افزايش بارش در آينده نسبت بـه دوره مشـاهداتى 
جدول • ا. مقايسه ميانخين مجموع بارش ماهانه در دوره مشاهداتى و آينده با توجه به سناريوهاى مختلف

\begin{tabular}{|c|c|c|c|c|c|c|c|}
\hline \multicolumn{2}{|c|}{ RCP 8.5} & \multicolumn{2}{|c|}{ RCP 4.5} & \multicolumn{2}{|c|}{ RCP 2.6} & \multirow[b]{2}{*}{ دوره مشاهداتى } & \multirow[b]{2}{*}{ Lool } \\
\hline$r \circ 90-r \circ 99$ & $Y \circ Y \circ-Y \circ \Delta Q$ & $r \circ 90-r \circ 99$ & $Y \circ Y \circ-Y \circ \Delta Q$ & $Y \circ 90-Y \circ 99$ & $Y \circ Y \circ-Y \circ \Delta Q$ & & \\
\hline$|4|$ & 1149 & 1149 & Irt & IKT & 1rs & $|\pi|$ & زانويه \\
\hline $1 \mu_{0}$ & ITO & IKA & Irr & ITA & ITY & 119 & فوريه \\
\hline Mr & $|r|$ & Iro & 119 & 110 & 111 & $11 r$ & مارس \\
\hline$\wedge \vee$ & $V^{c}$ & $\Lambda \Delta$ & VT & $\Delta \psi$ & VT & q & آوريل \\
\hline GY & 91 & 94 & GY & 90 & $4 \pi$ & \&V & مه \\
\hline ץへ & 44 & is & 49 & $4 q$ & \&V & 4 & ز زوئن \\
\hline Q० & 01 & ץ & 49 & $4 q$ & Q. & r & ز زوئيه \\
\hline V V & va & VQ & VV & VQ & V^ & 99 & اوت \\
\hline 109 & 195 & 101 & 191 & 109 & 194 & lor & سيتامبر \\
\hline rrq & TrA & TTV & TrV & rrv & rTV & TIV & أُكتبر \\
\hline 191 & 190 & 199 & 199 & Yoo & 199 & 1199 & ن امبر \\
\hline 190 & 109 & 190 & 109 & 191 & 190 & 101 & دسامبر \\
\hline
\end{tabular}

جدول 11. مقايسه ميانگين دماى ماهانه در دوره مشاهداتى و آينده با توجه به سناريوهاى مختلف

\begin{tabular}{|c|c|c|c|c|c|c|c|}
\hline \multicolumn{2}{|c|}{ RCP 8.5} & \multicolumn{2}{|c|}{ RCP 4.5} & \multicolumn{2}{|c|}{ RCP 2.6} & \multirow[b]{2}{*}{ دوره مشاهداتى } & \multirow[b]{2}{*}{ ماoه } \\
\hline$r 090-r_{099}$ & $Y \circ Y \circ-Y \circ \Delta q$ & $r \circ 90-r \circ 99$ & $Y \circ Y \circ-Y \circ \Delta Q$ & $r \circ 90-r \circ 99$ & $r \circ Y \circ-Y \circ 09$ & & \\
\hline$V / q$ & $V / 9$ & $v / r$ & $V / I$ & $9 / 1$ & $9 / 0$ & $9 / 9$ & زانويه \\
\hline$\Lambda / 1$ & $V / q$ & $V / D$ & $V / 4$ & v & V & $V / \circ D$ & فوريه \\
\hline $10 / \mu$ & $10 / 1$ & $9 / 9$ & $9 / 4$ & $\Lambda / 4$ & $\Lambda / \Delta$ & $9 / \circ 0$ & مارس \\
\hline $19 / 4$ & $19 / 4$ & $10 / 1$ & $10 / 0$ & $10 / 1$ & $10 / 00$ & $14 / \wedge 0$ & آوريل \\
\hline$T M / D$ & $r I / r$ & $r \circ / 9$ & $r \circ / \Lambda$ & $r \circ / r Q$ & $r \circ / 90$ & $r \circ / \circ D$ & مه \\
\hline$r Q / Q$ & $r \Delta / r$ & $T Y / \Lambda$ & $Y Y / Q$ & $r M / A D$ & $T Y / \mu$ & $r M / Q$ & زوئن \\
\hline$T V / I$ & $r q / q$ & $r 9 / 9$ & $r \in / 4$ & $r Y / 90$ & $Y Y / \Lambda D$ & $r \& / 1$ & زئيه \\
\hline TS/V & $r \& / 4$ & $r 9 / 1$ & $r Q / q$ & $T Y / \mu$ & $T Y / Q$ & $r \Delta / 90$ & اوت \\
\hline 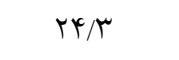 & $Y \Psi / l$ & Tr/V & $r \mu / 4$ & $r M / \circ D$ & rI & TM/l & ستيتامبر \\
\hline $1 \Lambda / V$ & $11 / 9$ & $1 / / 0$ & $\mid \Lambda / r$ & IV/VQ & $\mathrm{IV} / \mathrm{A}$ & $1 N / \circ 0$ & أُكتبر \\
\hline $14 / 4$ & $14 / \mu$ & $14 / 1$ & 14 & $1 \pi / \mu$ & $14 / 10$ & $1 \pi / \wedge \Delta$ & ن نوامبر \\
\hline $9 / 4$ & $9 / 1$ & $1 / 9$ & $\Lambda / \wedge$ & $\Lambda / Y Q$ & $N / Y$ & $1 / 9$ & دسامبر \\
\hline
\end{tabular}


حدى (دماى حداقل بهاره) نقش تعيين كنندهترى داشته و تعداد

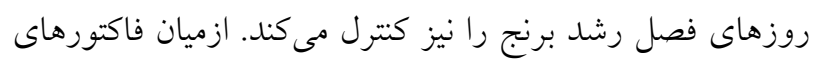

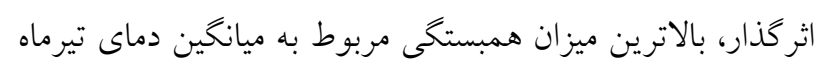

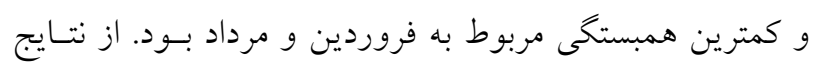

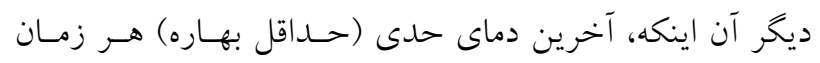

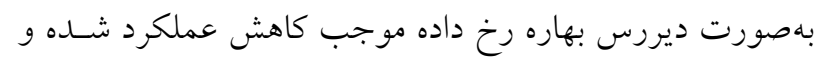

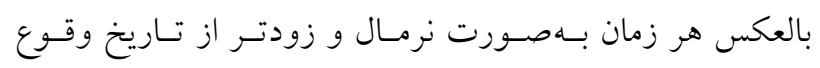

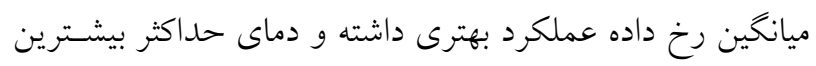

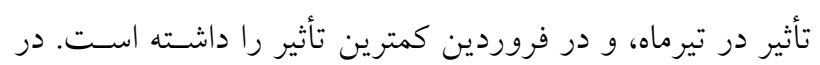

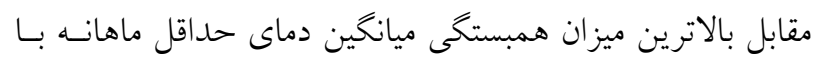

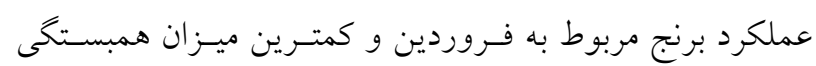

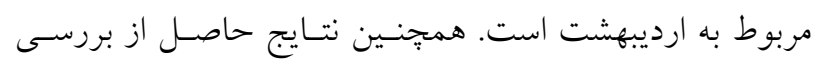

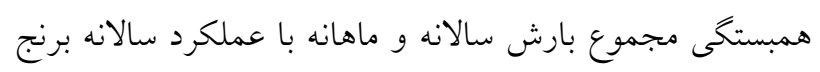

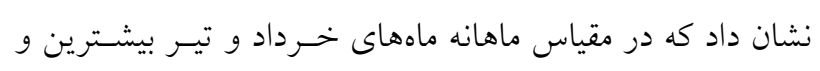

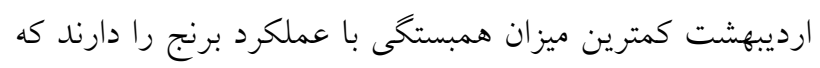

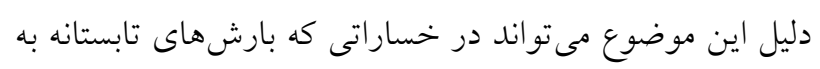

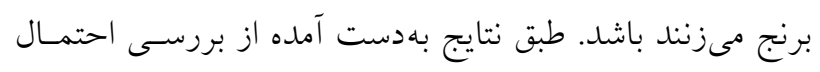

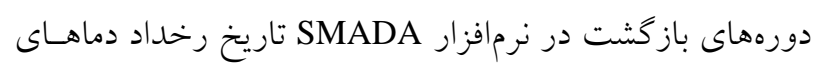

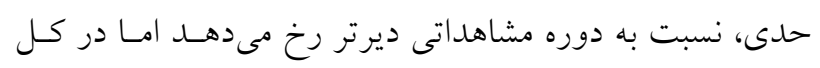
شاهد فصل رشد كوتاهترى نسبت به دوره مشـاهداتى خــواهيم

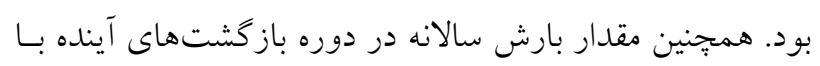

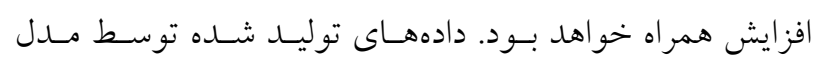

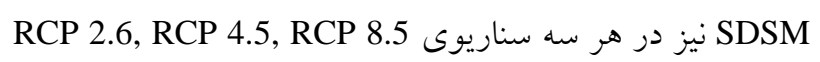

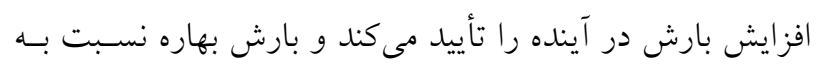

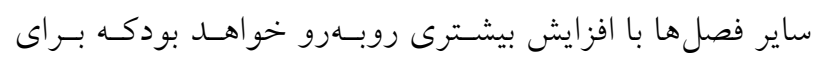
كشت برنج بسيار مناسب است.

\section{نتيجه گيرى}

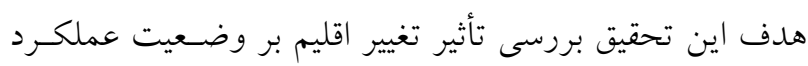

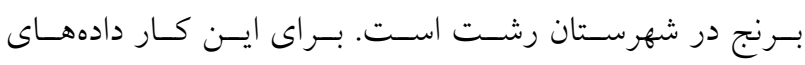

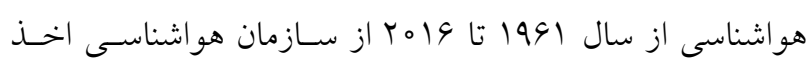

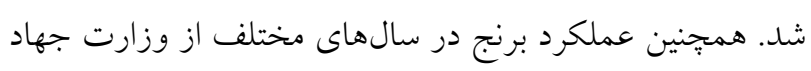

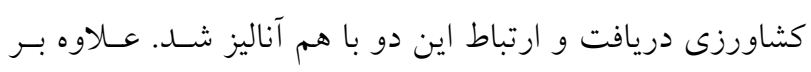

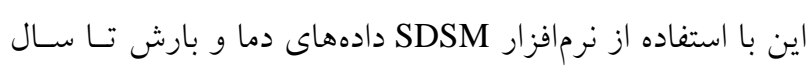

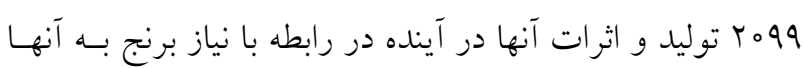

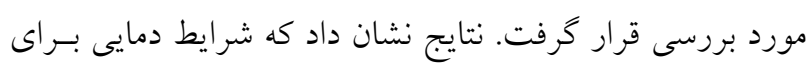

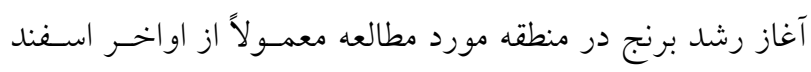

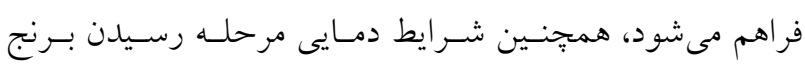

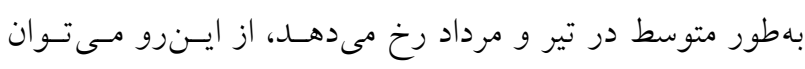

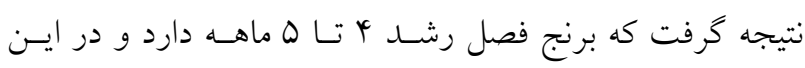

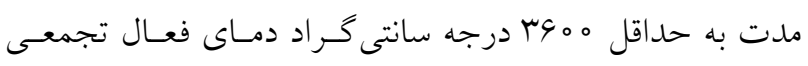

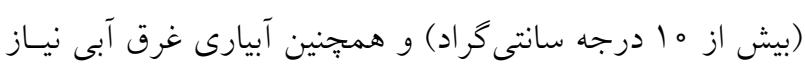

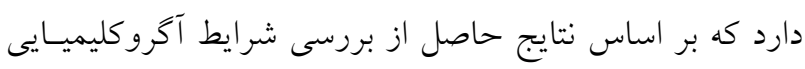

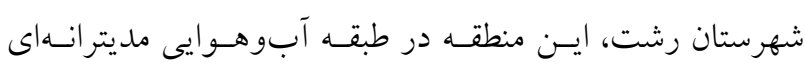

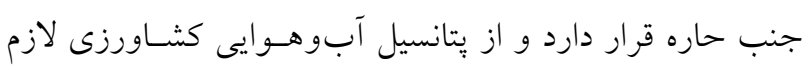

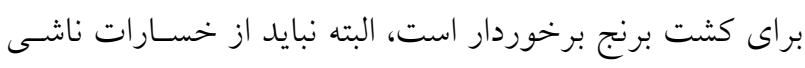

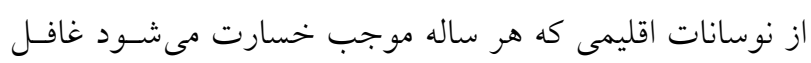

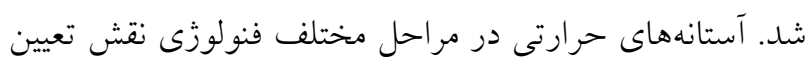

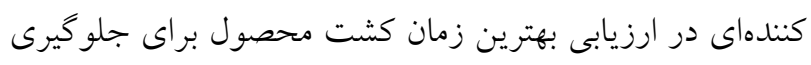

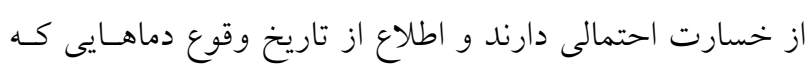

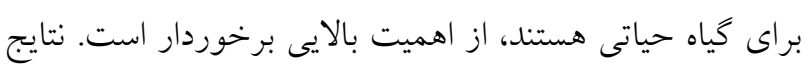

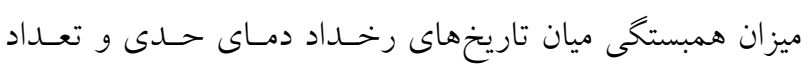

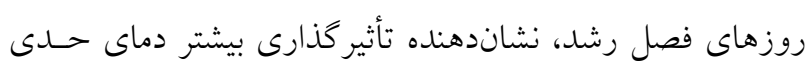

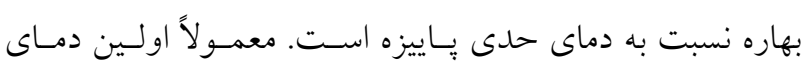

\section{منابع مورد استفاده}

1. Abassi, F., M. Habibi Nokhandan, L. Goli Mokhtari, S. Malbousi and Sh. Asgari. 2010. Climate change assessment over Iran in the future decades using MAGICC-SCENGEN model. Physical Geography Research Quarterly 42(72): 91-109.

2. Alizadeh, A. and K. Gholamali. 2002. Effects of climate change on increasing agricultural water consumption in Mashhad plain. Geographical Research 17(3-2): 189 -201. 
3. Allen, G. J. and R. A. Evorrt. 2001. Sodium transport measured in plasma membrane vesicles isolated from wheat genotypes with differing $\mathrm{K}^{+} / \mathrm{Na}^{+}$discrimination traits. Plant Cell Environment 18(4): 105-115.

4. Ashofteh. P. and A. R. Massah Bouani. 2010. Impact of climate change on maximum discharges case study of Aidoghmoush basin, East Azerbaijan. Journal of Water and Soil Science 14(53): 28-38.

5. Barimani, F., M. Saligheh and M. Karim Raisi. 2005. Climate impacted irrigation systems in baluchistan iran samples of aqueducts in Hichan. Geographical Research Quarterly 76: 38-52.

6. Farajzadeh, M. 2013. Climate change effects on river discharge-case study Sheshpir river. Geography and Environmental Planning 24(1): 17-32.

7. Ghadirnezhad, S. R. and A. Falah. 2013. Comparison of low and optimum temperature effects on morphological traits and yield of rice varieties at different growth stages. Journal of Crop Production Research 5(2): 155-164.

8. Haghtalab, N., M. Goodarzi, M. Habibi Nokhandan, A. Yavari and H. Jafari. 2013. Climate modeling in Tehran \& Mazandaran provinces by LARSWG and comparing changes in northern and southern Central Alborz hillside. Journal of Environmental Science and Technology 15(1): 37-49.

9. Hamidianpour, M., M. Baaghideh and M. Abbasnia. 2016. Assessment of the precipitation and temperature changes over south east Iran using downscaling of general circulation models outputs. Physical Geography Research Quarterly 48(1): 107-123. doi: 10.22059/jphgr.2016. 57030.

10. https://www.jkgc.ir

11. IPCC. 2007. Executive summary of the intergovernmental panel on climate change. https://www.ipcc.ch/. Accessed 1 APRIL 2007.

12. Khoshakhlagh, F., E. Gharibi and Z. Shafiei. 2011. The study of the lowest temperature changes in Iran. Geography and Environmental Planning 22(2): 199-216.

13. Moradpour, S., E. Amiri, H. Mobasser and H. Madani. 2016. The effects of planting date and plant density on rice in Mazandaran province. New Finding in Agriculture 9(2): 117-127.

14.OTA. 1993. Global change research and NASA's earth observing system. https://ota.fas.org/page/3/. Accessed 16 MAY 1993.

15. Sanikhani, H., Y. Deinpajo, S. Pouryousef and S. Zamanzad Ghavidel. 2014. The impacts of climate change on runoff in watersheds (Case study: Ajichay watershed in East Azerbaijan province, Iran). Journal of Water and Soil 27(6): 1225-1234. https://doi.org /10.22067 /jsw. v0i0.21513.

16. Shaemi, A. and Q. Azizi. 2005. Assessment of Iranian agricultural diversity and talents by papadakis method. Geographical Research Quarterly 36(3): 78-79.

17. Sharifi, P., H. Dehghani, A. Momeni and M. Moghadam. 2013. Study the genetic relations of some of rice agronomic traits with grain yield by using multivariate statistical methods. Iranian Journal of Field Crop Science 44(2): 273-282. doi: 10.22059/ijfcs.2013. 35116.

18. Shengxiang, T. 1995. Evaluation and utilization on cold tolerance of rice in south east Asia. Report of an INGER traveling workshop on low temperature stress of rice in China, Japan and Korea. Manila, Philippines 19(2): 13-20.

19. Sobhani, B., M. Eslahi and I. Babaeian. 2015. Efficiency of statistical downscaling models of SDSM and LARSWG in the simulation of meteorological parameters in Lake Urmia Basin. Physical Geography Research Quarterly 47(4): 499-516. doi: 10.22059/jphgr.2015.56046

20. Taei Semiromi, S., H. Moradi and M. Khodagholi. 2014. Simulation and prediction some of climate variable by using multi line SDSM and Global Circulation Models (Case study: Bar Watershed Nayshabour). Human \& Environment 12(28): 1-15.

21. Takeuchi, B. J., R. C. Babu, H. E. Shashidhar, J. M. Lilley and N. D. Thanh. 1969. Determine the minimum suitable temperature for rice germination in southeastern Asia. Plant Breeding 120: 233-238.

22. Zahiboun, B., M. R Goodarzi and A. Masah Bayani. 2010. Application of SWAT model to estimation of basin runoff in future periods affected by climate change. Climatological Research 1(3-4): 45-60.

23. Zhang, H. L., X. G. Zhao, S. L. Yin, J. F. LiuXue, M. Wang and F. Chen. 2015. Challenges and adaptations of farming to climate change in the north China Plain. Climatic Change 129(1): 213-224. 


\title{
The Effect of Climate Change on the Yield of Rice in the Rasht County
}

\author{
M. H. Naserzadeh*, B. Alijani and M. Payari ${ }^{1}$
}

(Received: June 21-2018 ; Accepted: September 17-2019)

\begin{abstract}
Given the climatic changes and threats to food security in recent years, they have have become a major issue in agricultural climatology. The present study aimed to investigate the status of agricultural climate suitable for the cultivation of rice in the light of the influential climatic conditions in the past. Given the effect of temperature and the amount of precipitations on rice growth and the sensitivity of rice to these two variables, the study examined the predicted future temperature and rainfall and their effects on rice. Data related to the temperature and rainfalls were obtained from the Meteorological Organization. Additionally, the temperature and agricultural potential of the region were considered. By preparing the agricultural calendar for the cultivation of rice, the correlation between temperature, precipitation and rice productivity was calculated using the Spearman Correlation coefficient. By using the SDSM model, future data and temperature and precipitation return period were determined in the SMADA software. The results demonstrated that minimum spring temperature tended to be late spring. The minimum temperature had the highest impact in April, the maximum temperature had the highest impact in July and the maximum rainfall had the highest effect in both June and July. Based on the results of the prediction models, the studied region would experience an increase in temperature and rainfall by providing favorable conditions for the cultivation of rice. However, delays in the cold season and shortness of the growth period increased the risks associated with the cultivation of rice in this period.
\end{abstract}

Keywords: Agro-climate, Temperature potential, Spearman correlation, SDSM model

1. Climatology, Faculty of Geography, Kharazmi University, Tehran, Iran.

*: Corresponding author, Email: nasserzadeh2100@yahoo.com 